\title{
Purification and Characterization of Alkaline Pectin Lyase from a Newly Isolated Bacillus clausii and Its Application in Elicitation of Plant Disease Resistance
}

\author{
Zuming Li • Zhihui Bai • Baoguo Zhang • Baojv Li • \\ Bo Jin • Michael Zhang • Francis Lin • Hongxun Zhang
}

Received: 21 January 2012 / Accepted: 29 May 2012 /

Published online: 14 June 2012

(C) Springer Science+Business Media, LLC 2012

\begin{abstract}
Alkaline pectin lyase (PNL) shows potential as a biological control agent against several plant diseases. We isolated and characterized a new Bacillus clausii strain that can produce 4,180 U/g of PNL using sugar beet pulp as a carbon source and inducer. The PNL was purified to apparent homogeneity using ultrafiltration, ammonium sulfate fractionation, DEAE Sepharose Fast Flow, and Sephadex G-75 gel filtration. The purified PNL was found to be a monomeric protein with a molecular weight of $35 \mathrm{kDa}$, as determined by sodium dodecyl sulfate polyacrylamide gel electrophoresis (SDS-PAGE). It demonstrated optimal activity with $K_{\mathrm{m}}$ of $0.87 \mathrm{mg} / \mathrm{ml}$ at $\mathrm{pH} 10.0$ and $60^{\circ} \mathrm{C}$. The enzyme is stable in the $\mathrm{pH}$ range of 8.0-10.0 and temperature $\leq 40{ }^{\circ} \mathrm{C}$. $\mathrm{Ca}^{2+}$ was found to stimulate the enzymatic activity of the PNL by up to $410 \%$. Mass spectrometric results gave $38 \%$ match coverage with pectate lyase from B. clausii KSM-K16 (gi|56961845). The PNL was found to elicit disease resistance in cucumber seedlings, suggesting that it may have applications in biocontrol and sustainable agriculture.
\end{abstract}

Keywords Bacillus clausii - Alkaline pectin lyase $\cdot$ Sugar beet pulp .

Mass spectrometric sequencing $\cdot$ Plant disease resistance

Z. Li

College of Arts and Sciences of Beijing Union University, Beijing 100191, China

Z. Li $\cdot$ Z. Bai $(\bowtie) \cdot$ B. Zhang $\cdot$ H. Zhang

Research Center for Eco-Environmental Sciences, Chinese Academy of Sciences, Beijing 100085, China e-mail: zhbai@rcees.ac.cn

B. $\mathrm{Li}$

Institute of Vegetables and Flowers, Chinese Academy of Agricultural Sciences, Beijing 100081, China

B. Jin

School of Chemical Engineering, the University of Adelaide, Adelaide SA 5005, Australia

M. Zhang $\cdot$ F. Lin

Department of Physics and Astronomy, University of Manitoba, Winnipeg R3T 2N2, Canada 


\section{Introduction}

Pectin, an important cell wall component in dicotyledonous plants, is a heteropolysaccharide composed of $\alpha$-1,4-linked galacturonate chains. It has a great degree of methyl esterification, which plays an important role in the adhesion of adjacent cells $[1,2]$. Enzymes that hydrolyze pectic substances are known as pectinases. Pectinases are today one of the upcoming enzymes of the commercial sector [3]. Based on their mode of action, pectinases include polygalacturonase, pectin esterase, pectin lyase (PNL), and pectate lyase [4]. Pectinases are classified as an endo- or exo-pectinase depending on whether the cleavages are random or endwise [5]. Pectinases can be broadly classified into acidic and alkaline groups on the basis of $\mathrm{pH}$ requirements for optimum enzymatic activity. For decades, alkaline pectinases have been used in many industrial and biotechnological processes, such as textile and plant fiber processing, coffee and tea fermentation, oil extraction, treatment of industrial wastewater containing pectinacious materials, purification of plant viruses, and paper manufacturing [6-8]. Although alkaline pectinases are used in industrial processes in crude form, their purification and the knowledge of the biochemical characteristics of these enzymes are essential for the understanding of their structure, mechanisms of action, and thermostability [9].

Food safety and environmental concerns associated with the use of chemical pesticides have drawn a great deal of attention to alternative and supplemental means of controlling plant pathogens and reducing the need for agrochemicals [10]. So far, very few reports have been published on plant disease resistance stimulated by pectinases $[11,12]$. This paper, then, is the first to investigate the elicitation of plant disease resistance by alkaline PNL.

Among all pectinases, PNLs are the only enzymes capable of depolymerizing highly esterified pectin into small molecules without prior action of other enzymes. PNLs cleave pectin by $\beta$-elimination mechanism that results in the formation of 4,5 unsaturated oligogalacturonates without affecting the ester content of the polymer chain which is responsible for specific aroma of fruits $[13,14]$. PNLs show specificity to methyl esterified substrates (pectin), while pectate lyases are specific to unesterified PGA (pectate) [15]. Because new applications for PNLs are emerging, the demand for these enzymes is increasing [2]. PNLs are mainly produced by fungal genera Aspergillus, Penicillium, and Fusarium, but there are few reports on bacterial and yeast PNLs [16]. To the best of our knowledge, there is no report on alkaline PNL from Bacillus clausii. Given the potential applications of alkaline PNLs in the food, paper, biological control, and textile industries, solid state fermentation (SSF) is an excellent avenue. Moreover, it also reduces costs, allows for the reuse of waste materials, and minimizes damage to the environment. It can increase enzyme yields using cheap and easily available matrices and agro-residues [2, 16, 17]. The properties of alkaline PNLs can contribute to the commercialization of these enzymes. Purification is necessary before characterization because crude enzyme may contain different stabilizing components and cause the final product's properties to vary [18]. Some studies have described the purification, characterization, production, and application of alkaline PNLs through a variety of microorganisms [2, 13, 16, 17, 19-24]. In the present investigation, we report the purification, characterization, and application of enzymes used to elicit plant disease resistance and the first instance of the production of an alkaline PNL from a newly isolated B. clausii using agro-residues in SSF. 


\section{Materials and Methods}

\section{Strain Isolation}

Samples were collected from alkaline soil and diluted in sterile $0.9 \% \mathrm{NaCl}$ solution. They were then plated on pectin agar plates with (w/v) $1.0 \%$ pectin (Sigma), $0.5 \%$ peptone, $0.5 \%$ yeast extract, $0.1 \% \mathrm{~K}_{2} \mathrm{HPO}_{4}, 0.02 \% \mathrm{MgSO}_{4} \cdot 7 \mathrm{H}_{2} \mathrm{O}$, and $0.6 \% \mathrm{Na}_{2} \mathrm{CO}_{3}\left(\mathrm{Na}_{2} \mathrm{CO}_{3}\right.$ was sterilized separately). Inoculated plates were incubated for $3-7$ days at $30{ }^{\circ} \mathrm{C}$. The incubated plates were dyed with $1.0 \%$ cetyltrimethyl ammonium bromide. Colonies with the clear zones were considered alkaline pectinase producers. Based on the diameter of its clear zones, isolate S-4 was established as a good alkaline pectinase producer and used in all further investigations.

\section{Phenotypic Characterization}

Phenotypic tests were performed according the method reported by Dong et al. [25]. The $\mathrm{pH}$ of the medium was adjusted to 9.0 by the addition of $10 \%$ sodium carbonate. All phenotypic assays for strain S-4 were performed in duplicate.

\section{Extraction and Amplifications of the $16 \mathrm{~S}$ rDNA}

The genomic DNA of isolate S-4 was extracted using a previously published extraction method. The gene coding for bacterial $16 \mathrm{~S}$ rDNA was amplified from strain S-4 with primer pair 27f (5'-AGAGTTTGATCMTGG CTCAG, M = C:A) and 1492r (5'-TACGGY TACCTTGTTACGACTT, $\mathrm{Y}=\mathrm{C}: \mathrm{T})$. These are standard primers appropriate for most bacteria. The product represents $>97 \%$ of the $16 \mathrm{~S}$ rDNA sequence (Escherichia coli standard). PCR cycling was performed with an Applied Biosystems Gene Amp PCR system 2700. PCR amplification reaction conditions were as previously described [7].

DNA Sequencing and Nucleotide Accession Number

Amplified products of the appropriate size $(1.5 \mathrm{~kb})$ were sequenced by BGI LifeTech Co., Ltd., China. The $16 \mathrm{~S}$ rDNA sequence of isolate S-4 reported in this article was submitted to the GenBank nucleotide sequence database under accession no. AY825251. A phylogenetic tree was constructed based on the partial $16 \mathrm{~S}$ rDNA sequences of 14 strains similar to strain S-4.

\section{Inoculum Culture Conditions}

The medium used for liquid inoculum culture contained the following $(\% \mathrm{w} / \mathrm{v})$ : peptone 1.5 , yeast extract 0.3 , glucose $0.2, \mathrm{NaCl} 0.2, \mathrm{~K}_{2} \mathrm{HPO}_{4} 0.12$, and $\mathrm{Na}_{2} \mathrm{CO}_{3} 0.3$. After sterilization by autoclaving at $115^{\circ} \mathrm{C}$ for $15 \mathrm{~min}$, the medium $(60 \mathrm{ml})$ was placed in a $250-\mathrm{ml}$ Erlenmeyer flask, inoculated, and cultivated at $35^{\circ} \mathrm{C}$ by shaking at $150 \mathrm{rev} / \mathrm{min}$ for $24 \mathrm{~h}$.

\section{Solid State Fermentation Conditions}

The medium used for alkaline PNL production contained $10 \mathrm{~g}$ dry sugar beet pulp as a carbon source and inducer and $4.0 \mathrm{~g}$ dry wheat bran as a nitrogen source. This mixture was moistened with $40 \mathrm{ml}$ liquid medium (comprising $\mathrm{KH}_{2} \mathrm{PO}_{4} 0.075 \%, \mathrm{MgSO}_{4} \cdot 7 \mathrm{H}_{2} \mathrm{O} 1.2 \%$, 
$\mathrm{Na}_{2} \mathrm{CO}_{3} 0.6 \%$ ). After sterilization at $115{ }^{\circ} \mathrm{C}$ for $15 \mathrm{~min}$ in a $500-\mathrm{ml}$ Erlenmeyer flask, the combined medium was inoculated with $3 \mathrm{ml}$ of a 24-h-old inoculum culture. The cultures were incubated statically under humid conditions $(75 \%)$. Different incubation temperatures were chosen within the range of $30-45^{\circ} \mathrm{C}$. For enzyme extraction, $50 \mathrm{ml} 0.05 \mathrm{~mol} / 1 \mathrm{Na}_{2} \mathrm{CO}_{3}-$ $\mathrm{NaHCO}_{3}$ buffer $(\mathrm{pH} \mathrm{10.0)}$ was added to each flask and stirred for 30 min on a rotary shaker at $80 \mathrm{rev} / \mathrm{min}$. The crude extract of solid cultivation was centrifuged at 9,000 rev/min for $20 \mathrm{~min}$ to remove the cells and debris and then the supernatant was used for enzyme activity assays.

\section{Ultrafiltration}

The crude enzyme extract (0.5 1) was concentrated to $160 \mathrm{ml}$ using a hollow fiber cross-flow ultrafiltration module fitted with a polysulfone membrane $\left(10,000 M_{\mathrm{r}}\right.$ cutoff) and $0.10 \mathrm{~kg} / \mathrm{cm}^{2}$ transmembrane pressure. The concentrated enzyme was dialyzed by the addition of $500 \mathrm{ml}$ $2.5 \mathrm{mmol} / 1 \mathrm{Na}_{2} \mathrm{CO}_{3}-\mathrm{NaHCO}_{3}$ buffer ( $\mathrm{pH} 10.0$ ). It was again concentrated to $160 \mathrm{ml}$ by ultrafiltration. This process was repeated eight times. The dialyzed enzyme solution, which was designated as the crude enzyme, was stored at $4{ }^{\circ} \mathrm{C}$ in the presence of sodium azide $(0.1 \mathrm{~g} / \mathrm{l})$.

\section{Ammonium Sulfate Fractionation}

Initially, ammonium sulfate was gradually added up to $500 \mathrm{~g} / 1$ saturation with stirring at $4{ }^{\circ} \mathrm{C}$ and the crude enzyme solution was allowed to stand for up to $1 \mathrm{~h}$ in a refrigerator. It was then centrifuged at 9,000 rev/min for $20 \mathrm{~min}$ and the pellets were discarded. The supernatant was again saturated with ammonium sulfate up to $600 \mathrm{~g} / \mathrm{l}$ and allowed to stand overnight. It was then centrifuged at 9,000 rev/min for $20 \mathrm{~min}$. The active fraction $(500 \mathrm{~g} / \mathrm{l}-600 \mathrm{~g} / \mathrm{l})$ was dissolved in $50 \mathrm{mmol} / \mathrm{l} \mathrm{Na} \mathrm{HPO}_{4}-\mathrm{KH}_{2} \mathrm{PO}_{4}$ buffer ( $\mathrm{pH}$ 6.0) and dialyzed against the same buffer at $4{ }^{\circ} \mathrm{C}$.

\section{DEAE Sepharose Fast Flow}

The dialyzed enzyme solution was loaded on DEAE Sepharose Fast Flow (Pharmacia) column $(10 \mathrm{~mm} \times 200 \mathrm{~mm})$ equilibrated with $50 \mathrm{mmol} / 1 \mathrm{Na}_{2} \mathrm{HPO}_{4}-\mathrm{NaH}_{2} \mathrm{PO}_{4}$ buffer ( $\mathrm{pH}$ 6.0). After being washed in the same buffer, the protein adsorbed on the column was eluted with a linear gradient of $\mathrm{NaCl}$ in the range of $0 \mathrm{~mol} / \mathrm{l}-2 \mathrm{~mol} / \mathrm{l}$ in the equilibrating buffer at a flow rate of $15 \mathrm{ml} / \mathrm{h}$. The major active fractions were pooled, concentrated, and dialyzed against $50 \mathrm{mmol} / 1 \mathrm{Na}_{2} \mathrm{CO}_{3}-\mathrm{NaHCO}_{3}$ buffer ( $\mathrm{pH} 9.0$ ).

\section{Sephadex G-75 Gel Filtration}

The resultant dialysate was applied to a Sephadex G-75 column $(16 \mathrm{~mm} \times 800 \mathrm{~mm})$ that had been equilibrated with $50 \mathrm{mmol} / 1 \mathrm{Na}_{2} \mathrm{CO}_{3}-\mathrm{NaHCO}_{3}$ buffer ( $\mathrm{pH} 9.0$ ). Elution was carried out with the same buffer at a flow rate of $15 \mathrm{ml} / \mathrm{h}$. The major active fractions were collected, concentrated, and dialyzed. Homogeneity of the major active fractions was confirmed by sodium dodecyl sulfate polyacrylamide gel electrophoresis (SDS-PAGE) as described below.

Enzyme Assays

The activity of the alkaline PNL in the cell-free supernatant was determined spectrophotometrically by measurement of the increment of unsaturated compounds at $235 \mathrm{~nm}$ absorbance from pectin as previously reported [2]. Diluted enzyme solution $(0.5 \mathrm{ml})$ was added to 
2-ml pectin solution (pectin from apples with 70-75\% esterification, $0.3 \%$, w/v; sodium bicarbonate-sodium carbonate buffer $0.05 \mathrm{~mol} / \mathrm{ml}, \mathrm{pH} \mathrm{10.0)}$ and incubated at $60{ }^{\circ} \mathrm{C}$ for $15 \mathrm{~min}$. Changes in absorbance were monitored. One unit of PNL activity was defined as the amount of enzyme capable of releasing $1 \mu \mathrm{mol}$ of aldehyde groups per minute under the conditions described above. The experiments were run in triplicate and all standard deviations were under $5 \%$.

The activity of endopectinases was measured by the AJDA method [11]. One unit of endopectinase activity was defined as the amount of enzyme capable of degrading $1 \mathrm{mg}$ pectin (from citrus fruits, methoxy content $8 \%(\mathrm{w} / \mathrm{w})$, Sigma) at $\mathrm{pH} 10.0$ and $40{ }^{\circ} \mathrm{C}$ in half an hour.

\section{Determination of Protein Content}

Protein content was determined by the method described by Lowry with bovine serum albumin (Pharmacia) as the standard [26]. After column chromatography, the protein concentration was estimated by measuring the absorbance at $280 \mathrm{~nm}$.

\section{Electrophoresis}

SDS-PAGE was performed using $12 \%$ (w/v) acrylamide in gels as described by Laemmli to check the homogeneity of the enzyme and determine the molecular weight [27]. Protein bands were visualized by staining the gel with Coomassie brilliant blue R250. Low-range molecular weight markers (Pharmacia) were used for the estimation of molecular weight of purified enzyme.

\section{Effects of pH, Temperature, and Metal Ions on Enzyme Activity}

The optimum $\mathrm{pH}$ of the purified enzyme was determined by performing a standard enzyme assay in the appropriate $50 \mathrm{mmol} / \mathrm{l}$ buffer, such as $\mathrm{Na}_{2} \mathrm{CO}_{3}-\mathrm{NaHCO}_{3}(\mathrm{pH}$ 9.0-10.5) and glycine- $\mathrm{NaOH}(\mathrm{pH} 11.0-11.5)$ within a $\mathrm{pH}$ range of $9.0-11.5$. The stability of the purified enzyme was examined by measuring the residual activity under standard assay conditions after incubating the enzyme mixture for $30 \mathrm{~min}$ at $40{ }^{\circ} \mathrm{C}$ at the indicated $\mathrm{pHs}$ in $50 \mathrm{mmol} /$ 1 buffers, such as $\mathrm{KH}_{2} \mathrm{PO}_{4}-\mathrm{Na}_{2} \mathrm{HPO}_{4}\left(\mathrm{pH} 7.0-8.0\right.$ ), $\mathrm{Na}_{2} \mathrm{CO}_{3}-\mathrm{NaHCO}_{3}$ (pH 9.0-10.0), and glycine- $\mathrm{NaOH}(\mathrm{pH} 11.0)$. The effect of temperature on purified enzyme activity was examined under standard assay conditions within a temperature range of $45-70{ }^{\circ} \mathrm{C}$. The thermal stability of the purified enzyme was examined by measuring residual activity after the enzyme mixture was incubated $(\mathrm{pH} 10.0)$ for $30 \mathrm{~min}$ at each desired temperature between $30{ }^{\circ} \mathrm{C}$ and $60{ }^{\circ} \mathrm{C}$. The effects of various metal ions on the activity of the purified enzyme were determined under standard assay conditions with the addition of $1.0 \mathrm{mmol} / \mathrm{l}$ of metal ions at the optimum $\mathrm{pH}$ and temperature given in the literature $[2,13,17]$.

\section{Kinetic Determinations}

The $K_{\mathrm{m}}$ value was determined by the double-reciprocal plot method described by Lineweaver-Burk. All assays were performed at the optimal temperature and $\mathrm{pH}$ of the enzyme being tested.

\section{Mass Spectrometric Sequencing}

To determine the amino acid sequence of the purified alkaline PNL, the protein was separated by $12 \%$ SDS-PAGE. The relevant band was then cut out from the $12 \%$ SDS- 
PAGE gel after Coomassie blue staining and digested with trypsin. The resulting samples were subjected to MALDI-TOF/TOF mass spectrometry for protein identification at the Beijing Proteome Research Center (China). MALDI MS-MS experiments were performed on a 4800 MALDI-TOF/TOF analyzer (Applied Biosystems, MA, USA) equipped with Nd: YAG laser at excitation wavelength $355 \mathrm{~nm}$. All the mass spectra were obtained in positive reflection mode after being calibrated via an internal calibration with known $\mathrm{m} / \mathrm{z}$ values of peptides originating from myoglobin. The spectra were then analyzed using Data Explorer (version 4.5). The MS and $\mathrm{MS}^{2}$ spectra were evaluated using MASCOT embedded in GPS software (Applied Biosystems, MA, USA). They were tested against the NCBI (2009) database at precursor tolerance of $0.2 \mathrm{Da}$ and $\mathrm{MS} / \mathrm{MS}$ fragment tolerance of $0.3 \mathrm{Da}$. One missed cleavage was allowed in trypsin digestion. Methionine oxidation and alkylation by iodoacetamide were selected as variable modifications.

\section{Elicitor Bioassay}

Cucumber seedlings were obtained from the Institute of Vegetables and Flowers, Chinese Academy of Agricultural Sciences. Thirty specimens with no signs of necrosis or mechanical damage were used for each assay. Experiments were run in triplicate. According to preliminary tests, the alkaline PNL produced by the strain S-4 to was diluted with filters and sterilized $0.3 \mathrm{~mol} / \mathrm{L} \mathrm{Na}_{2} \mathrm{CO}_{3} / \mathrm{NaHCO}_{3}$ buffer ( $\mathrm{pH} 8.0$, containing $0.02 \%$ Tween 20 ) to 35 $\mathrm{U} / \mathrm{ml}$. The alkaline PNL solution and the sterilized buffer $(\mathrm{pH} \mathrm{8.0)}$ that served as control were separately sprayed on the cucumber seedlings once every 2 days. After three treatments, several pathogens (Botrytis cinerea, Pseudoperonospora cubensis, Sphaerotheca fuliginea, Cladosporium cucumerinum, Colletotrichum orbiculare, and Pseudomonas syringae) were separately inoculated onto the plant seedlings. When the diseases were clearly seen to have developed on the control cucumber seedlings, the infective index and decrease in incidence of each disease in the treated cucumber seedlings were determined using guidelines described by the National Standard Methods of China [28].

\section{Results and Discussion}

\section{Morphological and Physiological Characteristics of Isolate S-4}

The strain S-4, isolated from a sample of alkaline soil, exhibited visible clear zones around the colonies on agar plates with pectin as the sole carbon source. Following staining with $1 \%$ cetyltrimethyl ammonium bromide, S-4 was selected as a good producer of alkaline pectinase. The taxonomic characteristics of isolate S-4 are summarized in Table 1. It has been seen that strain S-4 is a Gram-positive, strictly aerobic, spore-forming, rod-shaped bacterium $(0.4-0.6 \times 1.0-3.0 \mu \mathrm{m})$ which forms white colonies on agar. The cells were able to grow at $\mathrm{pH}$ values between 7.5 and 12 and in the presence of $2-12 \% \mathrm{NaCl}$ at $\mathrm{pH} 9.0$. The cells were also able to grow within the temperature range of $15{ }^{\circ} \mathrm{C}-55^{\circ} \mathrm{C}$. The phenotypic properties of isolate S-4 and reference strain B. clausii DSM 8716 appeared to be similar (Table 1) [29]. Differences were observed in growth at $55{ }^{\circ} \mathrm{C}$ and hydrolysis of Tween 20. They also showed nearly identical results in carbohydrate utilization tests. Both are able to use L-arabinose, glycerol, D-arabinose, D-xylose, galactose, glucose, fructose, mannose, rhamnose, mannitol, sorbitol, $\alpha$-methyl-D-glucoside, cellobiose, maltose, lactose, raffinose, sucrose, and starch. Isolate S-4 can use sorbose but B. clausii DSM 8716 cannot. Both are able to use sodium nitrate as a nitrogen source. 
Table 1 Phenotypic properties of the isolate S-4 and reference strain B. clausii DSM 8716
${ }^{\text {a }}$ Results obtained from Nielsen et al. (1995)

\begin{tabular}{|c|c|c|}
\hline Properties & $\mathrm{S}-4$ & B. clausii DSM $8716^{\mathrm{a}}$ \\
\hline Form & Rod & Rod \\
\hline Spore & + & + \\
\hline Gram stain & + & + \\
\hline $\mathrm{NO}_{3}$ to $\mathrm{NO}_{2}$ & + & + \\
\hline \multicolumn{3}{|l|}{ Growth at } \\
\hline $10^{\circ} \mathrm{C}$ & - & - \\
\hline $15^{\circ} \mathrm{C}$ & + & + \\
\hline $20^{\circ} \mathrm{C}$ & + & + \\
\hline $37^{\circ} \mathrm{C}$ & + & + \\
\hline $45^{\circ} \mathrm{C}$ & + & + \\
\hline $50{ }^{\circ} \mathrm{C}$ & + & + \\
\hline $55^{\circ} \mathrm{C}$ & + & - \\
\hline $60{ }^{\circ} \mathrm{C}$ & - & - \\
\hline $\mathrm{pH} 7$ & - & + \\
\hline $\mathrm{pH} 7.5$ & + & \\
\hline $\mathrm{pH} 8$ & + & + \\
\hline pH 9 & + & \\
\hline $\mathrm{pH} 10$ & + & - \\
\hline $\mathrm{pH} 11$ & + & \\
\hline \multicolumn{3}{|l|}{ Growth in } \\
\hline $5 \% \mathrm{NaCl}$ & + & + \\
\hline $7 \% \mathrm{NaCl}$ & + & + \\
\hline $8 \% \mathrm{NaCl}$ & + & + \\
\hline $10 \% \mathrm{NaCl}$ & + & + \\
\hline $12 \% \mathrm{NaCl}$ & + & - \\
\hline $15 \% \mathrm{NaCl}$ & Weakly & \\
\hline $20 \% \mathrm{NaCl}$ & Weakly & \\
\hline $25 \% \mathrm{NaCl}$ & - & \\
\hline \multicolumn{3}{|l|}{ Hydrolysis of } \\
\hline Gelatine & + & + \\
\hline Starch & + & + \\
\hline Tween 20 & + & - \\
\hline Tween 60 & - & - \\
\hline Tween 80 & - & \\
\hline Arginine hydrolase & + & \\
\hline Lysine hydrolase & - & \\
\hline Urease & - & \\
\hline Deamination of phenylalanine & - & - \\
\hline
\end{tabular}

16 S rDNA Sequence Analysis and Phylogeny

The $16 \mathrm{~S}$ rDNA sequence of strain S-4 was established and the gene sequence was submitted to the GenBank database under accession number AY825251. Comparison with other $16 \mathrm{~S}$ rDNA genes revealed similarity with $B$. clausii strains. The most similar identities were over 
$99.5 \%$. For example, the sequences of the alkaliphilic B. clausii DSM 8716, B. clausii N/R 84, B. clausii KSM-K16, and B. clausii XJU-5 showed $99.6 \%, 99.8 \%, 99.9 \%$, and $99.9 \%$ homology, respectively, with isolate S-4. In order to understand the phylogenetic position of strain S-4, we constructed a phylogenetic tree based on comparison of $16 \mathrm{~S}$ rDNA sequences of the isolate to those of Bacillus strains (Fig. 1).

By examining morphological and physiological characteristics and evaluating its $16 \mathrm{~S}$ rDNA gene sequence, strain S-4 was identified as a strain of B. clausii. So far, PNLs have been found in the species of Aspergillus, Acrophialophora, Penicillium, Fusarium, Geobacillus, Erwinia, Alternaria, Colletotrichum, Pseudomonas, Rhizoctonia, Bacillus, Cystofilobasidium, Penibacillus, Pythium, and Rizopus [2, 13, 16, 17, 19-24]. However, finding new sources of enzymes is helpful to display new specificities [30]. To our knowledge, no report has yet discussed the purification, characterization, and application of alkaline PNL from $B$. clausii. Because applications of alkaline PNLs can be very popular, it is important to discover new strains producing enzymes with novel properties and understand the nature and properties of these enzymes for their efficient and effective usage.

Enzyme Production

Alkaline PNL production by B. clausii S-4 has been found to be largely affected by fermentation conditions, such as incubation temperature and time. Figure 2 shows a SSF of alkaline PNL form S-4 using sugar beet pulp and wheat bran as the prime solid substrates at different temperatures and incubation times. Enzyme secretion occurred over the temperature range of $30{ }^{\circ} \mathrm{C}$ to $45^{\circ} \mathrm{C}$, and the optimum temperature was found to be $40{ }^{\circ} \mathrm{C}$. No other

Fig. 1 A phylogenetic tree based on $16 \mathrm{~S}$ rDNA sequences of the strain B. clausii S-4 and the alkaliphilic Bacillus strains. Bootstrap values (expressed as percentage of 100 replications) are shown at branch points. Bar refers to the distance corresponding to five nucleotide substitutions per 100 nucleotides

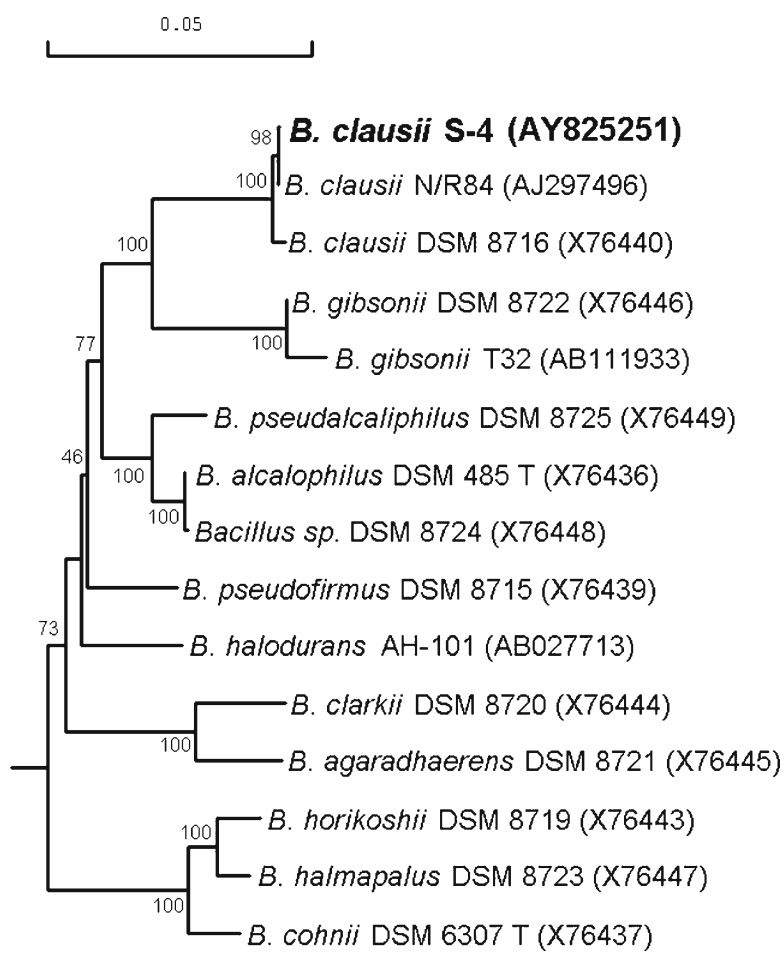


Fig. 2 Alkaline pectin lyase production by B. clausii S-4 at different temperatures. filled square $30^{\circ} \mathrm{C}$; filled triangle $35{ }^{\circ} \mathrm{C}$; filled circle $40{ }^{\circ} \mathrm{C}$; filled diamond $45^{\circ} \mathrm{C}$

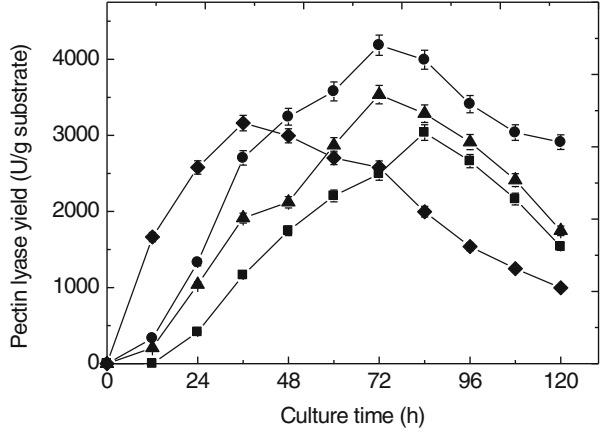

temperature was found to be suitable for enzyme secretion. At $40{ }^{\circ} \mathrm{C}$, enzyme production began after $12 \mathrm{~h}$ of incubation and peaked at $72 \mathrm{~h}$, decreasing gradually thereafter. Similarly, Ahlawat et al. reported the alkaline pectinase production by $B$. subtilis at an optimal temperature of $37{ }^{\circ} \mathrm{C}$ [4]. The maximum alkaline PNL yield of 4,180 U/g dry sugar beet pulp was obtained after $72 \mathrm{~h}$ of incubation at $40{ }^{\circ} \mathrm{C}$ with sugar beet pulp as a carbon source and wheat bran as a nitrogen source. Maximum production of exo-pectinase from A. niger in SSF DMF 45 under optimum conditions was reported to be $34.2 \mathrm{U} / \mathrm{g}$ [31]. More recently, a maximum production of $5,943 \mathrm{U} / \mathrm{g}$ of alkaline pectinase production from $\mathrm{B}$. subtilis SS was achieved under SSF [8]. Improvement in process with cost reduction can play a major role in the commercial success of any technology [8]. The production of pectinases by microorganisms have been studied with several natural and purified carbon sources, and a great attempt have been done for the utilization of agroindustrial wastes like wheat bran, lemon peel, apple, and orange bagasses [32]. Although the production of alkaline pectinase and PNL by SSF has been reported extensively, no report describes the use of sugar beet pulp in alkaline PNL production in SSF [4, 7]. The beet sugar industry is one of the most important industries in northern China. Large amounts of sugar beet pulp - a waste product - contain abundant pectin that may be used as carbon sources for the induction of pectinase. SSF has emerged as a preferred technology in industrial fermentation because it offers several practical and economical advantages $[16,17]$. This would not only lower costs but also reduce waste and protect the environment. Taking into account results published in existing literature, B. clausii S-4 can be considered an alternative alkaline PNL producer.

\section{Enzyme Purification}

The alkaline PNL obtained from SSF using B. clausii S-4 was purified to 45.0-fold with a yield of $5.5 \%$ (Table 2 ) by a combination of ultrafiltration, ammonium sulfate fractionation, and chromatographic procedures. The concentrated and dialyzed crude PNL was purified to

Table 2 Purification of alkaline pectin lyase from $B$. clausii $\mathrm{S}-4$ 
a specific activity of $6.6 \mathrm{U} / \mathrm{mg}$. The results of the purification procedure are summarized in Table 2. Of the total enzyme, $57.6 \%$ was precipitated between $50 \%$ and $60 \%$ of ammonium sulfate saturation and the specific activity increased to $15.2 \mathrm{U} / \mathrm{mg}$. During DEAE Sepharose Fast Flow column, most of the enzyme activity was present in the first protein peak. The specific activity went up to $49.5 \mathrm{U} / \mathrm{mg}$ and the recovery was $12.1 \%$. During gel filtration chromatography, most of the activity was present in the first protein peak. The major alkaline PNL was purified to apparent homogeneity. This was confirmed by SDS-PAGE (Fig. 3). The purified enzyme showed a specific activity of $297.1 \mathrm{U} / \mathrm{mg}$ with a yield of $5.5 \%$ (Table 2). These values may not necessarily correspond with those from other sources because of high levels of interlaboratory variability and because alkaline pectinolytic enzymes differ from one another with respect to their mechanism of action $[18,19]$. For example, the alkaline PNL from Aspergillus flavus MTCC 7589 was purified 58.01-fold to a yield of $10.29 \%$ with a specific activity of $18.33 \mathrm{U} / \mathrm{mg}$, while a polygalacturonase was purified 14.66-fold from the culture filtrate of Fusarium moniliforme NCIM 1276 to a yield of $0.15 \%$ with a specific activity of $18.66 \mathrm{U} / \mathrm{mg}[2,33]$. The major alkaline PNL was determined to be alkaline endoPNL because it not only demonstrated alkaline PNL activity but also showed alkaline endopectinase activity. These results are similar to those reported for alkaline PNL from Fusarium oxysporum sp. [20].

Molecular Weight

The molecular weight of the alkaline PNL purified from B. clausii S-4 was estimated to be $35 \mathrm{kDa}$ by SDS-PAGE (Fig. 3) and 35,875 Da by MALDI-TOF/TOF mass spectrometry

Fig. 3 SDS-PAGE of purified alkaline pectin lyase from $B$. clausii S-4. Lane $M$ markers, lane $P N L$ purified alkaline pectin lyase

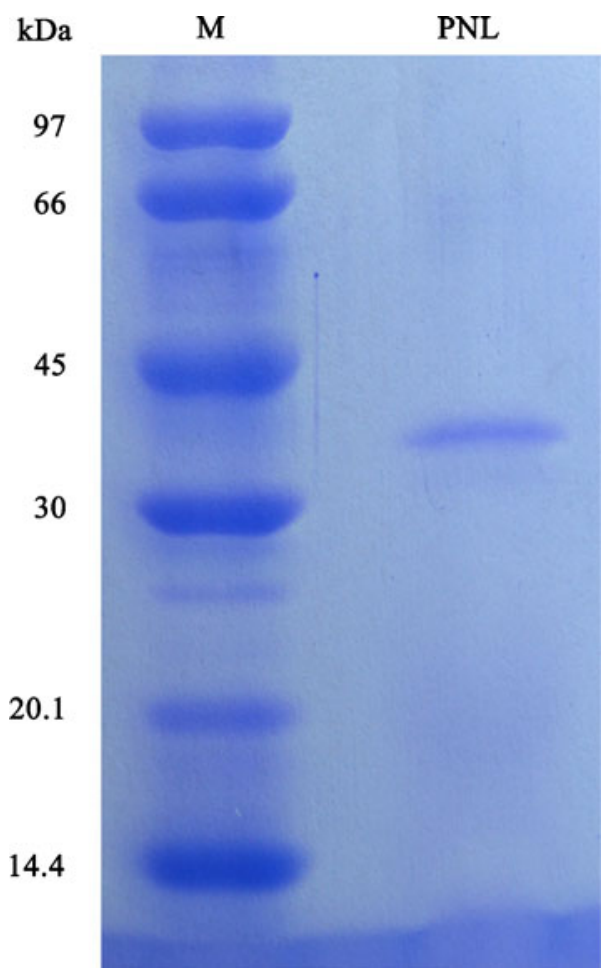


(Fig. 5), indicating that the alkaline PNL produced extracellularly is a monomeric protein. This is in accordance with several earlier reports showing the molecular weight of alkaline PNLs from Aspergillus terricola MTCC 7588 to be approximately $35 \pm 01 \mathrm{kDa}$ as estimated by SDS-PAGE [13]. Reports also list the molecular weight of pectinase from Acrophialophora nainiana as approximately $35,500 \mathrm{Da}$ and $30,749 \mathrm{Da}$ as determined by SDS-PAGE and mass spectrometry, respectively [19]. However, molecular weights of $30 \mathrm{kDa}, 38 \pm$ $01 \mathrm{kDa}, 50 \mathrm{kDa}$, and $18 \mathrm{kDa}$ were found for hybrids of Aspergillus flavipes and Aspergillus niveus $\mathrm{CH}-\mathrm{Y}-1043$, A. flavus MTCC 7589, Penicillium oxalicum, and F. oxysporum f. sp. radicis-lycopersici, respectively [2, 20, 23, 24].

Optimum $\mathrm{pH}$ and Temperature

The effect of $\mathrm{pH}$ on alkaline PNL activity was examined at $40{ }^{\circ} \mathrm{C}$ in $50 \mathrm{mmol} / \mathrm{l}$ buffer. As shown in Fig. 4a, the enzyme remained active over a broad $\mathrm{pH}$ range, displaying over $50 \%$ of its activity between 9.0 and 10.5 , with an optimum $\mathrm{pH}$ of 10.0 . This corresponds to values reported for F. oxysporum sp. (pH 9.5) [20] but not to those reported for A. flavus MTCC 7589 ( $\mathrm{pH} 8.0)$, A. terricola MTCC 7588 (pH 8.0), Penicillium adametzii (pH 8.0), A. nainiana ( $\mathrm{pH} 8.0$ ), hybrids of A. flavipes and A. niveus $\mathrm{CH}-\mathrm{Y}-1043$ ( $\mathrm{pH} 8.0)$, or P. oxalicum $(\mathrm{pH} 8.0)[2,13,19,22-24]$. PNLs that remain active under alkaline conditions are commercially important in the paper and textile industries. However, the utilization of alkaline PNLs has only drawn attention in recent years $[2,16,21]$. The results of the studies on the

Fig. 4 Optima and stability of (a) $\mathrm{pH}$ value and (b) temperature of purified alkaline pectin lyase. Filled square Optima curve. The maximum activity was interpreted as $100 \%$. Filled circle Stability curve. The original activity before preincubation was set as $100 \%$
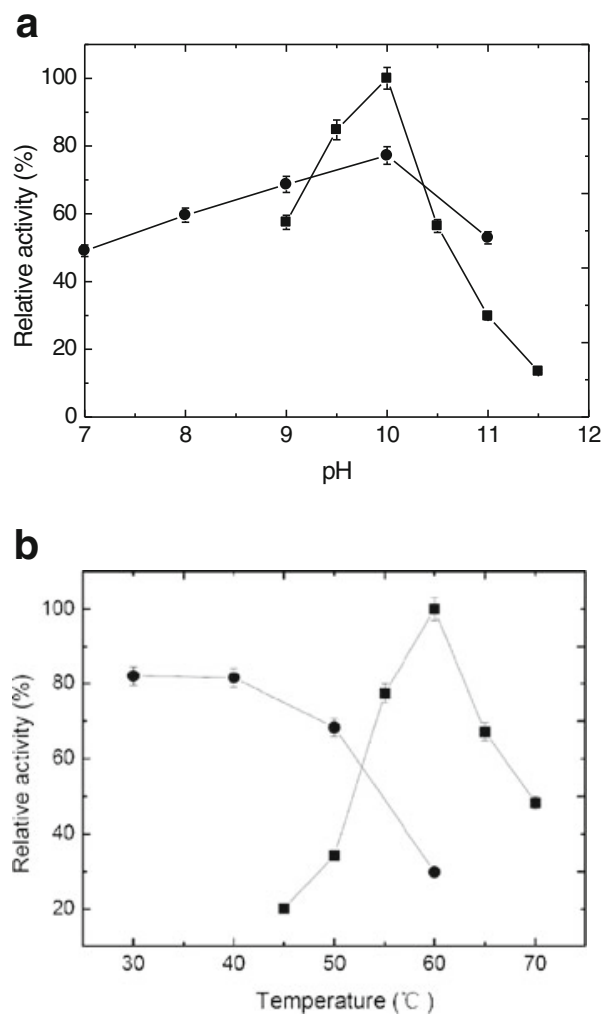
pH stability of purified alkaline PNLs are shown in Fig. 4a. The graph shows that the enzyme was stable within a $\mathrm{pH}$ range of 8.0-11.0, retaining more than $50 \%$ of its activity. In contrast, the alkaline PNL from A. flavus MTCC 7589 appeared to be stable within the pH range 4.0-10.0 when exposed for $24 \mathrm{~h}$ at $10^{\circ} \mathrm{C}$. Its activity may be lost at $\mathrm{pH} 10.0$ [2].

The effect of temperature on alkaline PNL activity was examined at $\mathrm{pH} 10.0$ in 50 $\mathrm{mmol} / 1 \mathrm{Na}_{2} \mathrm{CO}_{3}-\mathrm{NaHCO}_{3}$ buffer. The optimal temperature for activity was as high as $60{ }^{\circ} \mathrm{C}$ (Fig. 4b). It retained more than $60 \%$ of its activity between $55{ }^{\circ} \mathrm{C}$ and $65{ }^{\circ} \mathrm{C}$. This corresponds with the results of studies conducted by several authors using different strains. For example, the optimum temperature for alkaline PNL from $P$. adametzii was $60{ }^{\circ} \mathrm{C}$ [22]. Similarly, the maximum activity for the enzyme from $A$. nainiana was found to occur at $60{ }^{\circ} \mathrm{C}$ [19]. However, the optimal temperature of $50{ }^{\circ} \mathrm{C}$ was reported for alkaline PNL from $A$. terricola MTCC 7588, A. flavus MTCC 7589, hybrids of A. flavipes and A. niveus CH-Y1043, F. oxysporum sp., and P. oxalicum [2, 13, 20, 23, 24]. The thermal stability of the alkaline $\mathrm{PNL}$ was evaluated by incubating an enzyme aliquot at various temperatures ranging from $30^{\circ}$ $\mathrm{C}$ to $60{ }^{\circ} \mathrm{C}$ for $30 \mathrm{~min}$, assaying residual activity, and plotting percent residual activity against temperature. As shown in Fig. 4b, increases in temperature corresponded with an overall decline in stability, although $68.3 \%$ of activity was recovered after incubating the purified alkaline PNL at $50{ }^{\circ} \mathrm{C}$ for $30 \mathrm{~min}$. There was only a $29.9 \%$ restoration of activity after incubation at $60{ }^{\circ} \mathrm{C}$ for $30 \mathrm{~min}$. The enzyme appeared to be stable within a temperature range of $30{ }^{\circ} \mathrm{C}$ to $50{ }^{\circ} \mathrm{C}$, retaining more than $68 \%$ of its activity.

\section{Effect of Metal Ions}

Metal ions are known to affect amino acid residues both at the active site and the exterior surface of enzymes, inducing alterations in charge and distorting structure [34]. For this reason, we evaluated the effects of different types of metal ions on enzyme activity. Chlorides of $\mathrm{Ca}^{2+}$ and sulfates of $\mathrm{Cu}^{2+}, \mathrm{Mg}^{2+}, \mathrm{Mn}^{2+}$, and $\mathrm{Zn}^{2+}$ were added to enzyme solutions at $1 \mathrm{mmol} / \mathrm{l}$. Results are summarized in Table 3. It was noted that $\mathrm{Ca}^{2+}$ and $\mathrm{Mg}^{2+}$ ions stimulated enzyme activity up to $410.5 \%$ and $105.8 \%$ that of unexposed control enzymes, respectively. $\mathrm{Zn}^{2+}$ ions inhibited enzyme activity by $55.4 \%$, and $\mathrm{Cu}^{2+}$ and $\mathrm{Mn}^{2+}$ ions both stopped enzyme activity entirely. In various studies, different results were seen for different ions and alkaline pectinase sources. For example, the activity of alkaline PNL from A. flavus MTCC 7589 was inhibited by $\mathrm{Ag}^{+}, \mathrm{Cu}^{2+}, \mathrm{Hg}^{2+}, \mathrm{Ca}^{2+}, \mathrm{Mg}^{2+}, \mathrm{Zn}^{2+}$, and $\mathrm{K}^{+}$ions and slightly promoted by $\mathrm{Co}^{2+} . \mathrm{Mn}^{2+}$ had no effect [2]. The alkaline PNL activity of Penicillium citrinum MTCC 8897 was inhibited by $\mathrm{Ag}^{+}, \mathrm{Cu}^{2+}, \mathrm{Hg}^{2+}, \mathrm{Mn}^{2+}, \mathrm{Zn}^{2+}, \mathrm{Mg}^{2+}, \mathrm{K}^{+}$, and $\mathrm{Na}^{+}$ and slightly stimulated by $\mathrm{Ca}^{2+}$ and $\mathrm{Co}^{2+}$ ions [17]. The activity of alkaline pectinase from A. nainiana was inhibited by $\mathrm{Cu}^{2+}, \mathrm{Ca}^{2+}, \mathrm{Mn}^{2+}$, and $\mathrm{Zn}^{2+}$ ions, while $\mathrm{Mg}^{2+}$ had no effect [19]. Our results are partly in agreement with those seen in prevailing literature. The purified

Table 3 Effects of metal ions on the activity of alkaline pectin lyase

\begin{tabular}{ll}
\hline Metal ions $(1.0 \mathrm{mmol} / \mathrm{L})$ & Relative activity (\%) \\
\hline $\mathrm{Control}$ & 100 \\
$\mathrm{Ca}^{2+}\left(\mathrm{CaCl}_{2}\right)$ & $410.5 \pm 19.2$ \\
$\mathrm{Mg}^{2+}\left(\mathrm{MgSO}_{4}\right)$ & $105.8 \pm 4.5$ \\
$\mathrm{Zn}^{2+}\left(\mathrm{ZnSO}_{4}\right)$ & $44.6 \pm 2.1$ \\
$\mathrm{Cu}^{2+}\left(\mathrm{CuSO}_{4}\right)$ & 0 \\
$\mathrm{Mn}^{2+}\left(\mathrm{MnSO}_{4}\right)$ & 0
\end{tabular}


alkaline PNL was inhibited by $\mathrm{Zn}^{2+}, \mathrm{Cu}^{2+}$, and $\mathrm{Mn}^{2+}$ ions, like the alkaline PNL from $A$. flavus MTCC 7589, alkaline pectinase from $A$. nainiana, and alkaline PNL from $P$. citrinum MTCC 8897 [2, 17, 19]. The purified alkaline PNL was markedly activated by $\mathrm{Ca}^{2+}$ ions, much like the alkaline PNL from $P$. citrinum MTCC 8897 [17]. However, $\mathrm{Ca}^{2+}$ inhibited the enzyme activity of PNL from $A$. flavus MTCC 7589 and A nainiana [2, 19]. One species of Aspergillus has been reported to produce a calcium-dependent PNL $[2,16]$. Alkaline PNLs are in high demand in the textile industry, where they are used for retting plant fibers such as ramie, sunn hemp, jute, flax, and hemp $[2,13,16]$. The alkaline PNL from B. clausii S-4 may also have such applications.

\section{Substrate Specificity and Kinetic Analysis}

When the degradation rate of apple pectin ( $70 \%$ to $75 \%$ esterification, Sigma) was taken as $100 \%$, the relative rates toward sodium polygalacturonate (Sigma) were $20.8 \%$. Similarly, it has been reported that alkaline PNL from $F$. oxysporum sp. showed high specificity for pectin [20]. The kinetic parameter of the purified enzyme was determined by measuring steady state velocities of the enzyme-catalyzed reaction at different substrate concentrations [17]. The $K_{\mathrm{m}}$ value of the purified alkaline PNL from B. clausii S-4 for hydrolysis toward apple pectin (70\% to $75 \%$ esterification, Sigma) at $\mathrm{pH} 10.0$ and $60{ }^{\circ} \mathrm{C}$ were obtained through the double-reciprocal plot method described by Lineweaver-Burk. The estimated $K_{\mathrm{m}}$ value for hydrolyzing apple pectin was $0.87 \mathrm{mg} / \mathrm{ml}$. This is lower than that reported for most other microorganisms' alkaline PNLs: The $K_{\mathrm{m}}$ of alkaline PNL from $A$. terricola is 1.0, that of PNL from Aspergillus oryzae is 1.36, that of PNL from Paenibacillus amylolyticus is 4.6, that of PNL from Cystofilobasidium capitatum is 36.6, that of PNL from Penicillium italicum is 15.0, that of PNL from P. oxalicum is 1.1, that of PNL from Pseudomonas fluorescens is 3.2, and that of PNL from Rizopus oryzae is $3.87[13,16]$. The $K_{\mathrm{m}}$ of alkaline PNL from B. clausii S-4 is higher than that of PNL from A. flavus $(0.59 \mathrm{mg} / \mathrm{ml})$ [2]. The optimum $\mathrm{pH}$ (10.0) of the PNL from $B$. clausii S-4 is also higher than that of PNL from $A$. flavus (8.0). The lower $K_{\mathrm{m}}$ value means that the enzyme has higher affinity for the substrate.

\section{Amino Acid Sequence Analysis}

We performed sequencing by tandem mass spectrometry. The purified alkaline PNL was Coomassie stained on a SDS-PAGE gel showing a band corresponding to $35 \mathrm{kDa}$ (Fig. 3). This band was cut and digested with trypsin and the total digest was subjected to MALDITOF/TOF mass spectrometry. The peptide sequences obtained by mass spectrometry analysis were searched against the NCBI (2009) database. The results showed good alignment with a relatively high score of 864 . Table 4 shows the sequences of peptides obtained by digestion of the purified alkaline PNL. The sequences of 11 peptides were successfully determined by mass spectrometry with nine peptides confirmed by MS/MS. The longest peptide fragment of the protein, IHHVNTGDKDAISIEGPSK, was found to consist of 19 amino acid residues with a relatively high score of 149 . The shortest peptide fragment, ANNVIIR was found to consist of seven amino acid residues with a relatively low score of 41. These sequences were identical to those of the protein sequence of pectate lyase from $B$. clausii KSM-K16. Overall, the MS results gave $38 \%$ match coverage with the published amino acid sequences of pectate lyase from B. clausii KSM-K16 (gi|56961845) (Fig. 5). The nominal mass of pectate lyase from $B$. clausii KSM-K16 was found to be $35,875 \mathrm{Da}$, which is similar to the molecular mass of the purified alkaline PNL from B. clausii S-4 (35 kDa) (Fig. 3). The calculated $\mathrm{p} I$ value was 5.75. This differs from values reported for $P$. oxalicum 
Table 4 Peptides identified from the purified alkaline pectin lyase by MALDI-TOF/TOF mass spectrometry

\begin{tabular}{|c|c|c|c|c|c|c|}
\hline No. & Range & Sequence & $M_{\mathrm{r}}(\mathrm{expt})$ & $M_{\mathrm{r}}(\mathrm{calc})$ & Miss & $\begin{array}{l}\text { Confirmed by } \\
\text { MS/MS }\end{array}$ \\
\hline 1 & $117-123$ & ANNVIIR & 798.46 & 798.47 & 0 & + \\
\hline 2 & $127-145$ & IHHVNTGDKDAISIEGPSK & $2,017.02$ & $2,017.02$ & 1 & + \\
\hline 3 & $146-162$ & NIWVDHNELYNSLDVHK & $2,095.02$ & $2,095.01$ & 0 & - \\
\hline 4 & $163-173$ & DYYDGLFDVKR & $1,389.65$ & $1,389.66$ & 1 & + \\
\hline 5 & $191-204$ & SMLMGSSDSDSYGR & $1,491.59$ & $1,491.60$ & 0 & - \\
\hline 6 & $205-219$ & KITFHNNYFENLNSR & $1,895.91$ & $1,895.93$ & 1 & + \\
\hline 7 & $206-219$ & ITFHNNYFENLNSR & $1,767.82$ & $1,767.83$ & 0 & + \\
\hline 8 & $225-239$ & FGEAHIFSNYYADIR & $1,801.82$ & $1,801.84$ & 0 & + \\
\hline 9 & $253-260$ & IEENDFER & $1,050.45$ & $1,050.46$ & 0 & + \\
\hline 10 & $261-268$ & ANNPIVSR & 869.46 & 869.47 & 0 & + \\
\hline 11 & $272-282$ & EIGYWHLVNNR & $1,399.68$ & $1,399.70$ & 0 & + \\
\hline Sequence coverage & & & & & & $38 \%$ \\
\hline
\end{tabular}

+ Identified, - not identified

(5.0) and F. oxysporum sp. (9.20) [20, 24]. MALDI-TOF/TOF mass spectrometry analysis provided peptide mass and sequence information that facilitated confirmation of enzyme primary structure, allowing us to identify the purified alkaline PNL. The amino acid sequences of the peptides identified in alkaline PNL of B. clausii S-4 showed low match coverage with pectate lyase from B. clausii KSM-K16 (gi|56961845).

Elicitation of Plant Disease Resistance

Elicitation of plant disease resistance was tested with several strains of pathogen, $B$. cinerea, P. cubensis, S. fuliginea, C. cucumerinum, C. orbiculare, and $P$. syringae. The cucumber seedlings were treated separately with alkaline PNL solutions $(35 \mathrm{U} / \mathrm{ml}, \mathrm{pH} 8.0)$ and sterilized buffer ( $\mathrm{pH}$ 8.0). The seedlings' disease resistances are shown in Table 5. Results indicated that all of the seedlings treated with the crude alkaline PNL gained extensive

1 MVVFLLAFGA FSMPAYGQEG AEAANVNFSM QGFATLNGGT TGGAGGDVVT

51 VSTGDQLIAA LKNKKANTPL TIYINGTITP ANTSASKIDI KDVNDVSLLG

101 VGTNGELNGI GIKVWRANNV IIRNLKIHHV NTGDKDAISI EGPSKNIWVD

151 HNELYNSLDV HKDYYDGLFD VKRDADYITF SWNYVHDSWK SMLMGSSDSD

201 SYGRKITFHN NYFENLNSRV PSVRFGEAHI FSNYYADIRE AGINSRMGAQ

251 VRIEENDFER ANNPIVSRDS KEIGYWHLVN NRYVSSTGEQ PTVSTTTYNP

301 PYSYQATPVN QVKDVVRANA GVGVISP

Fig. 5 Amino acid sequence of purified alkaline pectin lyase obtained by MALDI-TOF/TOF mass spectrometry. Bold letters represent matching amino acids 
Table 5 Decreases in disease among cucumber seedlings treated with the alkaline pectin lyase

\begin{tabular}{|c|c|c|}
\hline Disease & Pathogen & Decrease $(\%)^{\mathrm{a}}$ \\
\hline Cucumber gray mildew & Botrytis cinerea & $58.6 \pm 10.3$ \\
\hline Cucumber downy mildew & Pseudoperonospora cubensis & $67.2 \pm 7.5$ \\
\hline Cucumber powdery mildew & Sphaerotheca fuliginea & $79.3 \pm 8.6$ \\
\hline Cucumber scab & Cladosporium cucumerinum & $40.5 \pm 6.7$ \\
\hline Cucumber anthracnose & Colletotrichum orbiculare & $66.7 \pm 9.3$ \\
\hline Cucumber angular leaf spot & Pseudomonas syringae & $53.8 \pm 7.1$ \\
\hline
\end{tabular}

${ }^{\text {a }}$ Decrease $(\%)=\left(\mathrm{ID}_{\text {control }}-\mathrm{ID}_{\text {treatment }}\right) / \mathrm{ID}_{\text {control }} \times 100 \% . \mathrm{ID}_{\text {control }}$ refers to the infective index of the plant

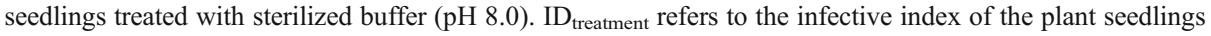
treated with alkaline pectin lyase solution $(35 \mathrm{U} / \mathrm{ml}, \mathrm{pH} 8.0)$. The experiments were run in triplicate

resistance against diseases. The decreases in gray mildew, downy mildew, powdery mildew, scab, anthracnose, and angular leaf spot among cucumber seedlings treated with PNL were found to be $58.6 \%, 67.2 \%, 79.3 \%, 40.5 \%, 66.7 \%$, and $53.8 \%$, respectively. It can then be concluded that alkaline PNL is involved in eliciting plant disease resistance. Induced resistance has been considered as a potential means of plant disease control [12]. Elicitor is a scientifically described term for stress factors that directly or indirectly trigger the inducible defense changes in a plant system that results in the activation of an array of protection mechanisms including induction or expansion of biosynthesis of fine chemicals which do have a major role in the adaptation of plants to the stressful environment. Biotic elicitors are the substances of biological origin that include polysaccharides originating from plant cell walls (pectin, cellulose, etc.), microorganisms (chitin, glucans, etc.), and G proteins which are bound to the receptors and act by activating or inactivating ion channels or enzymes [35]. A number of chemical compounds, microorganisms, and acidic pectinases have been reported to induce resistance against plant diseases [11]. The mechanism of pectinases eliciting plant diseases resistance is that they can degrade the pectin in plant tissues releasing cell wall oligosaccharides. The active pectic fragments of plant cell walls (oligosaccharides) can act as 'endogenous elicitors' and elicit plant defense reactions [12]. However, no report on induced resistance against plant diseases using alkaline PNL has yet been made. Laboratory tests have shown that the alkaline PNL can prevent common phytopathogens from attacking cucumber seedlings. This indicates that the alkaline PNL may have applications in biocontrol and sustainable agriculture.

\section{Conclusion}

The present study indicates that isolate S-4 is a strain of B. clausii. It is capable of utilizing sugar beet pulp as carbon source and inducer for alkaline PNL production by SSF. Characteristics of the purified alkaline PNL were found to be quite different from those of most alkaline PNLs. MS results gave $38 \%$ match coverage with published amino acid sequences of pectate lyase from B. clausii KSM-K16 (gi| 56961845). The alkaline PNL can elicit disease resistance in cucumber seedlings. This may decrease the need for chemical germicides and find potential applications in biocontrol and sustainable agriculture. 
Acknowledgments This work was supported by Subsidy for Outstanding People of Beijing (No. 2011A005022 000004), the "Knowledge Innovation" Program of Chinese Academy of Sciences (No. KZZD-EW-09-3), the National Key Technology R\&D Program of China (No. 2009BAC57B02), and Beijing Municipal Commission of Education (No. KM200811417006).

\section{References}

1. Serrat, M., Bermúdez, R. C., \& Villa, T. G. (2002). Applied Biochemistry and Biotechnology, 97, $193-208$.

2. Yadav, S., Yadav, P. K., Yadav, D., \& Yadav, K. D. S. (2008). Process Biochemistry, 43, 547-552.

3. Zeni, J., Cence, K., Grando, C. E., Tiggermann, L., Colet, R., Lerin, L. A., Cansian, R. L., Toniazzo, G., Oliveira, D., \& Valduga, E. (2011). Applied Biochemistry and Biotechnology, 163, 383-392.

4. Ahlawat, S., Dhiman, S. S., Battan, B., Mandhan, R. P., \& Sharma, J. (2009). Process Biochemistry, 44, 521-526.

5. Fahmy, A. S., El-beih, F. M., Mohamed, S. A., Abdel-Gany, S. S., \& Abd-Elbaky, E. A. (2008). Applied Biochemistry and Biotechnology, 149, 205-217.

6. Hoondal, G. S., Tiwari, R. P., Tewari, R., Dahiya, N., \& Beg, Q. K. (2002). Applied Microbiology and Biotechnology, 59, 409-418.

7. Li, Z., Bai, Z., Zhang, B., Xie, H., Hu, Q., Hao, C., Xue, W., \& Zhang, H. (2005). World Journal of Microbiology and Biotechnology, 21, 1483-1486.

8. Ahlawat, S., Mandhan, R. P., Dhiman, S. S., Kumar, R., \& Sharma, J. (2008). Applied Biochemistry and Biotechnology, 149, 287-293.

9. Damásio, A. R. L., Silva, T. M., Maller, A., Jorge, J. A., Terenzi, H. F., \& Polizeli, M. L. T. M. (2010). Applied Biochemistry and Biotechnology, 160, 1496-1507.

10. Chen, L., Wang, N., Wang, X., Hua, J., \& Wang, S. (2010). Bioresource Technology, 101, 8822-8827.

11. Bai, Z., Zhang, H., Qi, H., Peng, X., \& Li, B. (2004). Bioresource Technology, 95, 49-52.

12. Peng, X., Zhang, H., Bai, Z., \& Li, B. (2004). Phytoparasitica, 4, 377-387.

13. Yadav, S., Yadav, P. K., Yadav, D., \& Yadav, K. D. S. (2009). Applied Biochemistry and Biotechnology, 159, 270-283.

14. Baracat-Pereira, M. C., Coelho, J. L. C., Minussi, R. C., Chaves-Alves, V. M., Brandão, R. L., \& Silva, D. O. (1999). Applied Biochemistry and Biotechnology, 76, 129-141.

15. Gummadi, S. N., \& Kumar, D. S. (2008). Bioresource Technology, 99, 874-881.

16. Yadav, S., Yadav, P. K., \& Yadav, D. (2009). Process Biochemistry, 44, 1-10.

17. Yadav, S., Yadav, P. K., Yadav, D., \& Yadav, K. D. S. (2009). Biochemistry, 7, 800-806.

18. Jacob, N., Poorna, C. A., \& Prema, P. (2008). Bioresource Technology, 99, 6697-6701.

19. Celestino, S. M. C., Freitas, S. M., Medrano, F. J., Sousa, M. V., \& Filho, E. X. F. (2006). Journal of Biotechnology, 123, 33-42.

20. Guevara, M. A., González-Jaén, M. T., \& Estévez, P. (1996). Progress in Biotechnology, 14, 747-760.

21. Juárez, A. G. V., Dreyer, J., \& Göpel, P. K. (2009). Applied Microbiology and Biotechnology, 83, $521-527$.

22. Sapunova, L. I., Mikhailova, R. V., \& Lobanok, A. G. (1995). Applied Biochemistry and Microbiology, 3 , 228-231.

23. Solís, S., Loeza, J., \& Segura, G. (2009). Enzyme and Microbial Technology, 44, 123-128.

24. Yadav, S., \& Shastri, N. V. (2007). Indian Journal of Biochemistry \& Biophysics, 4, 247-251.

25. Dong, X., \& Cai, M. (2003). Identification manual of general bacteria. Beijing, China: Science Press.

26. Lowry, O. H., Rosebrough, N. J., \& Farr, A. L. (1951). Journal of Biological Chemistry, 193, $265-275$.

27. Laemmli, U. K. (1970). Nature, 7, 680-685.

28. Wu, X., Gu, B., Liu, N., \& Zhu, Q. (2000). Pesticide-guidelines for the field efficacy trials. Beijing, China: Standards Press of China.

29. Nielsen, P., Fritze, D., \& Priest, F. G. (1995). Microbiology, 141, 1745-1761.

30. Aminzadeh, S., Naderi-Manesh, H., Khajeh, K., \& Naderi-Manesh, M. (2006). Applied Biochemistry and Biotechnology, 135, 193-2108.

31. Patil, S. R., \& Dayanand, A. (2006). Bioresource Technology, 97, 2340-2344.

32. Pedrolli, D. B., Gomes, E., Monti, R., \& Carmona, E. C. (2008). Applied Biochemistry and Biotechnology, 144, 191-200.

33. Niture, S. K., \& Pant, A. (2004). Microbiological Research, 159, 305-314.

34. Guimarães, L. H. S., Somera, A. F., Terenzi, H. F., Polizeli, M. L. T. M., \& Jorge, J. A. (2009). Process Biochemistry, 44, 237-241.

35. Goel, M. K., Mehrotra, S., \& Kukreja, A. K. (2011). Applied Biochemistry and Biotechnology, in press. DOI 10.1007/s12010-011-9351-7. 